\title{
Managing Technology and Change in New Product Development (NPD): A Dynamic Capability Perspective
}

\author{
Mohamad Faizal Ahmad Zaidi \\ Lecturer, School of Technology Management and Logistics, College of Business \\ Universiti Utara Malaysia, 06010 Sintok, Kedah Malaysia \\ Email: mdfaizal@uum.edu.my
}

\section{Siti Norezam Othman}

Senior Lecturer, School of Technology Management and Logistics, College of Business

Universiti Utara Malaysia, 06010 Sintok, Kedah Malaysia

Email: snorezam@gmail.com

DOI: $\quad 10.6007 /$ IJARBSS/v4-i4/774 URL: http://dx.doi.org/10.6007/IJARBSS/v4-i4/774

\begin{abstract}
This paper derives from the perspective of dynamic capability (DC) that foresees sustainable competitive advantage can be achieved through firm's ability to continuously create alignment between new product development (NPD) and market need. By highlighting the inter-related issues, and with thorough critical review on the relevant literature, this paper proposes a conceptual framework for easy explanation of the concept. As a result, this paper contributes to better understanding of DC concept for managing technology and change in NPD. The potential areas for future studies are highlighted at the end of discussion.
\end{abstract}

JEL Classification: 031, 032, 033

Keywords: Alignment, Dynamic capability, Market need, New product development, Technological innovation capability

\section{Introduction}

In the world of business, there is no single competitive advantage that can be sustained for a very long time (Biedenbach \& Soderholm, 2008), unless the firm is timely responsive to the source of change (Wang, Klein, \& Jiang, 2007). Since the firm survival is threatened by its own failure to adapt to the source of change (Canibano, Encinar, \& Munoz, 2006), firm has no choice but to respond to the change in market (Cavusgil, Seggie, \& Talay, 2007) at the right time with the concept of dynamic capability (DC) (Wu \& Hisa, 2008). According to DC concept, to build a long-run flexible competitive advantage (Teece, Pisano, \& Shuen, 1997), firm must grasp the emerging opportunities under unexpected market conditions by reconfiguring its resources (e.g., new products) (Doving \& Gooderham, 2008). 
Ironically, even though DC concept is idealized for sustaining competitive advantage (Teece, 2007) where firm is capable of making decision, building new products, and creating alliances under volatile market environments (Eisenhardt \& Martin, 2000), some scholars have argued that DC is not necessarily sufficient to achieve that purpose (Zahra, Sapienza, \& Davidsson, 2006; Winter, 2003) since not all firms possessing DC is successful in their pursuing for higher performance level (Majumdar, 1999). As such, the quality of DC to explain the source of sustainable competitive advantage is debatable.

Nonetheless, since firms not only differs among themselves in the types of new product development (NPD) but also differs between NPD projects within the firm itself (Poolton \& Barclay, 1998), it appears the firm's ability to differentiate itself from others with DC makes its competitive advantage difficult to duplicate (Teece, Pisano, \& Shuen, 1997). Consequently, firm can be considered as possessing DC if it has the ability to continuously create alignment between NPD and market need. As such, DC concept offers potential for managing technology and change in NPD (Zaidi \& Othman, 2011a).

Since several issues need to be clarified, this paper attempts to close the gap by highlighting a conceptual framework for creating alignment between NPD and market need. For the building of the conceptual framework, a thorough critical review on the related literature should be performed. As the starting point of discussion, the inter-related issues of DC are addressed next.

\section{Issues in Dynamic Capability}

DC concept has gained great attention in the strategic management field since its introduction in the 90s (Cavusgil, Seggie, \& Talay, 2007). As the concept is still relatively new (Czakon, 2009), and filled with many debates (Zahra, Sapienza, \& Davidsson, 2006), its definition needs further clarification as none of the existing one is superior to best describe the concept (Wang \& Ahmed, 2007). Nonetheless, DC is commonly refers to "the firm's ability to integrate, build, and reconfigure internal and external competences to address rapidly changing environments", which is to achieve sustainable competitive advantage (Teece, Pisano, \& Shuen, 1997, p. 516). By using this definition as reference, several issues are highlighted (Zaidi \& Othman, 2012) as follows:

Firstly, the definition has described DC as the ability to integrate, build, and reconfigure resources, which is achieved through DC micro-foundations of opportunity sensing, opportunity seizing, and resource reconfiguration (Teece, 2007). In order for these micro-foundations to explain the source of sustainable competitive advantage, it has to be valuable, rare, inimitable, and non-substitutable (Teece, Pisano, \& Shuen, 1997), which suggests DC is not supposed to be transferable (Makadok, 2001). Ironically, some scholars have claimed the other way around where it should be transferable (Helfat \& Peteraf, 2003). As such, since there is no clear way on how to achieve (Salomo, Gemunden, \& Leifer, 2007) and foster DC (Wu, 2009), the concepts of opportunity sensing, opportunity seizing, and resource reconfiguration need further clarification.

Secondly, since most industries are characterized with dynamic market (Eisenhardt \& Martin, 2000), the key for quick NPD to market is the ability to respond to emerging demand and quickly rectify mistakes as soon as possible (Menon, Chowdhury, \& Lukas, 2002). This implies that the firm inability to change and response to the market need can cause failure as the product is losing value to the potential customers (Zirger \& Maidique, 1990). Ironically, market 
dynamism that is important part of DC is receiving lack of attention (Ho \& Tsai, 2006) as DC concept is mostly demonstrated to address rapidly technological change (Teece, Pisano, \& Shuen, 1997). For this reason, since business strategy will fail if market is inadequately predicted (Harreld, O'Reilly, \& Tushman, 2007), the roles of market dynamism in DC concept needs further attention.

Thirdly, DC is commonly used to address rapidly technological change (Teece, Pisano, \& Shuen, 1997). For instance, it has been associated to the emerging knowledge economy, global competition and technological advance (Lawson \& Samson, 2001), converging technologies (Bhutto, 2005), radical and new innovation (O'Connor, 2008), new product and process creations (Helfat, 1997), rapid development of new products (Deeds, DeCarolis, \& Coombs, 1999), and uncertainty of technological knowledge, lack of complementary technologies and developed markets (Marsh \& Stock, 2006), which are mostly technology-related issues. As the technological innovation capabilities themselves can be the source of change (Zahra, Sapienza, \& Davidsson, 2006), the firm's ability to manage technological innovation capabilities demands further investigation (Zaidi \& Othman, 2011a).

Fourthly, the contribution of NPD to the firm's performance is consistently declining despites a steady rate of NPD success (Cooper, 2005). This happen since most firms put too much emphasis on incremental NPD project than innovative NPD project (Barczak, Griffin, \& Kahn, 2009; Cooper, 2005), which has caused misalignment between NPD and market need. As the NPD management issues need to be emphasized in capability building, DC concept should be best and timely demonstrated for NPD (Zaidi \& Othman, 2011b).

In summary, the issues addressed above are inter-related topics because to sustain competitive advantage, firm needs to deploy the micro-foundations of DC (first issue), by sensing the market need (second issue), and seizing the technological innovation capability (third issue), which is then needed to reconfigure the NPD (fourth issue). Since the micro-foundations of DC are the basis of discussion, it would be crucial to understand what they are, which is the next topic of discussion.

\section{Micro-foundations of Dynamic Capability}

There are numerous DC concepts that have been proposed in literature and most of them are contextually dependents. Apparently, the one that has received greater attention is proposed by Teece (2007) with three micro-foundations, namely opportunity sensing, opportunity seizing, and resource reconfiguration, which are explained as follows:

Opportunity sensing involves scanning, searching, learning, exploring, and calibrating the market opportunities (or threats). Sensing is necessary especially when the market trajectory is hard to be predicted. New opportunities or threats can be sensed through the investment in researches and other activities as the information gathered from these activities may have created new knowledge that opens new opportunities. There are many ways in sensing the opportunities and threats such as through R\&D activities, and through competitors', customers', and/or suppliers' actions that have spotted or caused the change (Teece, 2007).

Opportunity seizing takes place after the market opportunities have been sensed and identified. Seizing involves decision making in what to invest especially when the domain designs is still unclear. As such, the firm should seizes the opportunity that is solving the customers' problems and when thing getting clear, firm must ready with the right timing to give full commitment to the related resources by grasping the technology that is most likely to be 
accepted by the marketplace. Seizing of particular opportunity can be secured through the commitment and loyalty building of the customers (Teece, 2007).

Resource reconfiguration involves recombination and reconfiguration of the firm's technological assets and organizational structures based on the market and technological opportunities that have been identified (sensing) and selected (seized). It also involves redesigning of the business model and realigning of the activities and routines in line with the changing environment to create fitness for the sustainability of profit growth (and competitive advantage) (Teece, 2007).

Since opportunity sensing is suitable for sensing market need, opportunity seizing is suitable for seizing technological innovation capability, and resource reconfiguration is suitable for reconfiguring NPD, it would be important to see how they fit into the pictures, which are the key discussions in the following sections.

\section{Opportunity Sensing of Market Need}

Since DC concept exists from the interactions between market dynamism, firm's capabilities, and the needs to sustain competitive advantage (Teece, Pisano, \& Shuen, 1997), DC application has been associated with the environment that is characterized with uncertainty and rapidly changing market. In general, market dynamism is related to the changing market needs that is referred to the needs of customers and other sources of change such as competitors, suppliers, government's policies, and anything that may possibly alter the rules of competition and firm's competitiveness, just as a "market insight involves a focus on understanding customer needs, competitor moves, technology developments, and market economics" (Harreld, O'Reilly, \& Tushman, 2007, p. 30). As it is hard to anticipate the pattern of needs under dynamic markets, the faster the needs change, the shorter the firm's competitive advantage will become as the change has caused the existing capabilities to be irrelevant (Biedenbach \& Soderholm, 2008). Specifically, market dynamism is characterized by a moderate to high velocity change. When the market is moderately dynamic, the change is predictable, stable, occur frequently, linearly, and with clear boundaries, while during high-velocity change the market is less predictable, unstable, nonlinear, and with unclear boundaries (Eisenhardt \& Martin, 2000). Meanwhile, the levels of market dynamism is different among industries and also different over time where at one time the environment can be characterized with high-level of market dynamism, while at other time can be characterized with low-level of market dynamism. For the purpose of this paper, market dynamism is categorized under low market dynamism and high market dynamism.

Since the uncertainties in market need makes the firm struggles to understand accurately to the new need, the problem is how firm should response effectively to the change (Bhutto, 2005)? Since the ability to understand and respond punctually to the changing need is crucial for building the right capability, firm should be able to scan any emerging trends in the market and focusing on the opportunities and threats that are in line with the firm objectives and then monitor the developments of these opportunities and threats with DC concept of opportunity sensing (Teece, 2007). As the market need sensed, firm should be responding to it by seizing the right technological innovation capability.

\section{Opportunity Seizing of Technological Innovation Capability}

Technological innovation capability refers to "the ability of a firm to make certain physical product" (Danneels, 2008, p. 520) that need to be continuously upgraded to sustain 
competitive advantage (Ray, Ida, Chung-Sok, \& Rhaman, 2004). As such, since the rate of technological innovation is significant for sustaining competitive advantage, firm need to be more "flexible, innovative and creative" (Biedenbach \& Soderholm, 2008, p. 124) to confront with the turbulent in market and uncertainty in technology (Kylaheiko \& Sandstrom, 2007). Continuous change in marketplace may bring early innovation (Zahra, Sapienza, \& Davidsson, 2006). As a result, the dynamic of technological innovation capability can determine the firm's ability to constantly build new product (Deeds, DeCarolis, \& Coombs, 1999), thus allowing the transformation of firm's resources into performance and generating profit (Wu \& Wang, 2007). However, since the firm's technology bases and strategies influences how its sees the worthiness of technology, the success is deemed by its efficiency and effectiveness at transferring the technology both inside and outside of the boundary (Teece, 2007). Thus, as the changes in technological capability will challenge the firm's competitiveness (Chen \& Lee, 2009), it must evaluate how the technology evolves and creates response to the customers, suppliers, competitors, policies makers, and change the natures of opportunity and competition through NPD.

Meanwhile, as technological innovation is related with high uncertainty, DC has been considered as a component of innovation process (Lee \& Kelley, 2008; Wang \& Ahmed, 2007). Hence, as product innovativeness is identified as one form of firm's capabilities (Cavusgil, Seggie, \& Talay, 2007), the more innovative the firm, the more DC it will become (Wang \& Ahmed, 2007). As such, since DC impacts the firm's innovation strategies through its business model (Kolk \& Puumann, 2008), DC is very important to assure the firm's survival (Wu, 2007). For these reasons, with the DC concept of opportunity seizing, firm should be able to select the emerging trends that are the most promising according to the firm objectives and then committed with the selected opportunity by applying relevant technological innovation capability with capital, man power, top level support, etc.

Firm has to rightly exploit and explore a different set of technological innovation capabilities to meet the change in market need (Teece, 2007) either with exploitation capability or exploration capability (Greve, 2007). Descriptively, exploitation capability refers to the capacity to build, refine, implement and execute new products with known competences for current viability of the firm, while exploration capability refers to the capacity to search, experiment, innovate and discover new product opportunities with new competences for future viability of the firm (e.g., Rothaermel \& Alexandre, 2009; Levinthal \& March, 1993; March, 1991). For the purpose of this paper, seizing of opportunities with technological innovation capability is performed either with exploitation capability and/or exploration capability.

Meanwhile, as the continuity of firm's business is at the risk when the environment it is dealing with is developing very fast (Wu \& Wang, 2007) with rapid introduction of new technology and a shorter lifecycle (Wu, 2007), building the right link between firm's technological innovation strategies and NPD activities is crucial (Marsh \& Stock, 2006). Since most studies on DC is about innovation and NPD (Zahra, Sapienza, \& Davidsson, 2006), firm should reconfigures its NPD with the right capability, which is our topic of discussion next.

6. Resource Reconfiguration of New Product Development

Basically, NPD is viewed "as a series of steps or activities [processes], including idea generation, product development, and product commercialization" (Song, Montoya-Weiss, \& Schmidt, 1997, p. 37). The processes also include concept generation, product design, engineering 
analysis, process analysis and design, and prototype product and testing (Cohen, Eliashberg, \& Ho, 1996). Since the critical processes of NPD are a necessity for the firm's survival (Craig \& Hart, 1992), it is becoming the most frequently researched area in NPD (Page, 1993). Because NPD processes are to create link between technological innovation capability and market need (Danneels, 2008; Dougherty, 1992), the proficiency in NPD processes of marketing and technical activities is increasing the levels of NPD success (Calantone, Schmidt, \& Song, 1996). For instance, previous study has shown the NPD performance is strongly related to the marketing (e.g., market need) and R\&D (e.g., technological innovation) capabilities (Krasnikov \& Jayachandran, 2008).

Meanwhile, there are two categories of product innovation according to 'newness' factors; first is the 'new to' factor that consists of new-to-the-world, new-to-the-industry, new-to-thescientific community, new-to-the-market, new-to-the-firm, and new-to-the-customer, and second is the 'new what' factor such as new technology, new product line, new product benefits/features, new product design, new process, new services, new competition, new customers and needs (Garcia \& Calantone, 2002). Similarly, NPD projects can be grouped into 'new-to-the-world', 'new-to-the-firm', 'next generation improvements', and 'incremental improvements' (Griffin, 2002). Nevertheless, since NPD is a process of building both incremental and radical new products (Hohenegger, Bufardi, \& Xirouchakis, 2007), for the purpose of this paper, NPD is categorized into incremental new product and radical new product.

Since most success firms rated NPD portfolio management as fundamental to business success where how to effectively investing, prioritizing, and allocating resources between product developments are the imperative issues (Cooper \& Edgett, 2001-2008), it appears different technological innovation capabilities have different effects on NPD performance under different levels of environmental turbulence (Calantone, Garcia, \& Droge, 2003). For this reason, firm should explore the related capabilities to be developed or acquired according to market opportunity, while at the same time exploiting and modifying the current capabilities according to availability of relevant resources (Teece, 2007). Therefore, as DC is "a set of practices aimed at enabling novel approaches for assembling and integrating resources [through NPD] to achieve innovative outcomes" (Lee \& Kelley, 2008, p. 156), firm's NPD (either incremental or radical new products) needs to be reconfigured such as by realigning the activities and routines with the environment to create fitness for sustainability of profit growth.

\section{Discussion of the Conceptual Framework}

With a brief discussion of DC micro-foundations (in Section 3) on opportunity sensing of market need (in Section 4), opportunity seizing of technological innovation capability (in Section 5), and resource reconfiguration of NPD (in Section 6), a conceptual framework for creating alignment between NPD and market need is proposed to clarify the inter-related issues (in Section 2). As displayed in Figure 1, even though each of DC micro-foundations can be used independently (Teece, 2007), to ease of explanation, this conceptual framework treats them all in series (as shown by the arrows) to address (respond) to the change in market need, which is explained as follows: 


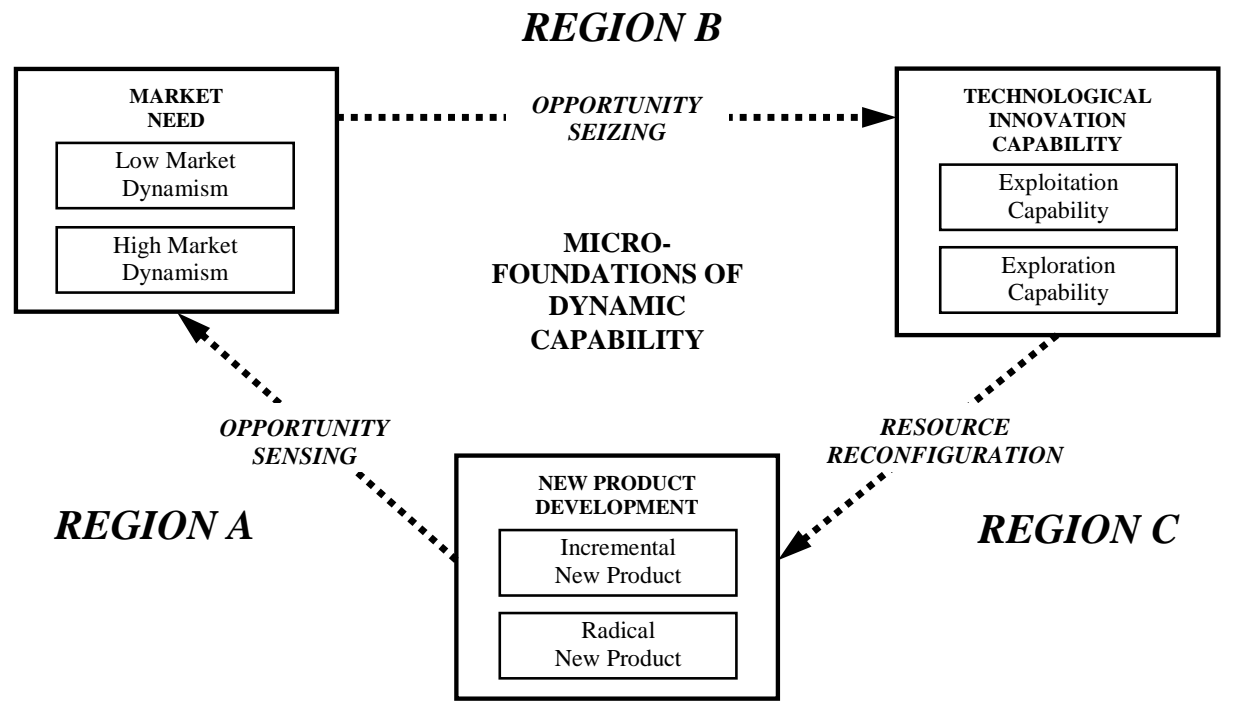

Figure 1

DC conceptual framework for managing technology and change in NPD

Firm and market are co-exist (Helfat, et al, 2007) where firm links to the marketplace by the product it offers. Meanwhile, since market need is influenced by environmental turbulence, market dynamism that is characterized with continuously changing market need is affecting product lifecycle (Eisenhardt \& Martin, 2000). As a result, this will cause misalignment between current product and market need. To what extent the firm's product performance is affected by the misalignment depends on the types of market dynamism. For instance, major change will cause serious misalignment between existing product and market need, while minor change will cause less damage to the alignment. Since business strategy will fail if market is inadequately predicted, the firm's ability to sense, scan, search, and explore market opportunities and threats (Teece, 2007) become critical under dynamic marketplace (Wu, 2006). Therefore, as environmental scanning is crucial at gathering information from the environment (Danneels, 2008), it turns out DC concept of opportunity sensing becomes critical to identify the types of market dynamism that trigger the change (See Region A in Figure 1).

When firm has successfully identified the types of market dynamism, firm must updates its product or develops new one according to the emerging need where constantly introduces new product is crucial to creates customer value (Liao, Kickul, \& Ma, 2009). Since NPD capability that are used to build new product is basically developed through and around technological innovation (Khalil, 2000), firm must seizes the right capability that addresses the emerging need, which is in this case either with exploitation capability or exploration capability. Seizing the right exploitation and/or exploration capabilities is critical because different types of technological innovation capability are needed to respond to different types of market dynamism. For instance, the capability for building new product under moderately dynamic change is based on rigid and detail structure that is more towards exploitation activity, while for high-velocity change, the capability for building new product is based on less rigid and simple structure that is more towards exploration activity (Eisenhardt \& Martin, 2000) (See Region B in Figure 1). 
After seizing the right technological innovation capability, firm must reconfigure the right NPD for exploiting or exploring new product. Since technological innovation involves exploitation activity to refine existing product competences, and exploration activity to pursuit new product competences (Danneels, 2008), it appears the exploitation capability should be used to build incremental new product and exploration capability to build radical new product. For instance, previous research has shown when demand is certain, customers orientation (incremental new product) is more effective than technology orientation (radical new product), but when demand is uncertain, technology orientation is greater than customer orientation (Zhou \& Li, 2009). As such, firm must reconfigure the right NPD according to technological innovation capability. Furthermore, as the structure for incremental new product is different from radical new product, firm must be capable of building the right structure for NPD. For these reasons, firm should be using the DC concept of resource reconfiguration to enable the firm to recombine and reconfigure its structures according to the market need and technological innovation capability that have been identified (sensing) and selected (seized) previously. It also helps firm to redesign the business model and realign the routines that suit the NPD to create fitness for sustainability of profit growth (Teece, 2007) (See Region C in Figure 1).

Since the ability of new product to meet the market need will guarantee continuous competitive advantage, firm can only be considered as successful if the new product is able to meet the market need. Therefore, when the product reaches the marketplace, the market's reaction towards the new product will decide how firm should take further actions. As such, monitoring the interactions between new product and market need with DC concept of opportunity sensing is (once again) crucial in ensuring the alignment is achieved. In this case the opportunity sensing helps firm to avoid two types of error in NPD projects, which are: (1) the potential failure project that is preceded because managers have ignored risk signals, and (2) the potential success project that is prematurely terminated because of lacking evidences for it success (Bonabeau, Bodick, \& Armstrong, 2008). At the end, the need to create alignment will be reduced when the fit between new product and market need is improved (Pan, Pan, \& Hsieh, 2006). Since continuously sensing the market and seizing the right capability is the way for sustainable competitive advantage (Harreld, O'Reilly, \& Tushman, 2007), the cycle will be repeated again once the alignment is affected by new market dynamism (See Region A in Figure 1).

\section{Potential Research Area}

This conceptual paper has demonstrated the concept of DC with opportunity sensing, opportunity seizing, and resource reconfiguration for creating alignment between NPD and market need. Even though this paper has clarified the inter-related issues in DC, the conceptual framework is still at the literature stage. Furthermore, even though this paper has clarified where and when each of DC concept of opportunity sensing, opportunity seizing, and resource reconfiguration should be used, how to acquire them were not discussed here. As such, an empirical study to investigate the conceptual framework should be initiated in near future. Besides that, there are at least two more potential areas (which are not stressed in this paper) for future investigations, as follows:

Firstly, even though the ability to manage specialized and/or co-specialized assets is crucial in building technological innovation capability to match rapidly changing environment, these skills do not always exists in the firm (Teece, 2007). As a result, firm that has no access to the related 
specialized and/or co-specialized assets will loss the potential profits from new product introduction as the advantage of becoming first-mover is possessed or accessed by others (followers or imitators) (Teece, 1986). Thus, the management of complementary assets will provide potential research area to explain how the complementarity among various technological innovation capabilities can be effectively used for building new product (Zaidi \& Othman, 2013) that is not just unique but also difficult-to-duplicate by competitors, hence, sustaining the firm's competitive advantage.

Secondly, since this study is taking the perspective of firm's abilities to exploit and explore the internal and external resources in response of dynamic environments, the monitoring activities that are important for NPD should be stressed (Guttel \& Konlechner, 2009; Schreyogg \& Kliesch-Eberl, 2007). This is because the monitoring of both internal and external activities are the keys for continuously creating alignment between NPD and market need. To do so, the monitoring activities need to capture the right signals of market dynamism and match it with the right types of NPD. Therefore, the mechanisms to monitor the interactions between market need and NPD should be investigated further.

\section{Conclusion}

This conceptual paper provides clarification on several inter-related issues in DC by explaining the concept through alignment of NPD and market need for sustainable competitive advantage. This is performed via opportunity sensing of market need, opportunity seizing of technological innovation capability, and resource reconfiguration of NPD. As demonstrated through the conceptual framework, since consumers are interested in the products rather than the capabilities that are used to produce the products, the right capabilities have to be translated into the right products according to the market needs. As the alignment of complementary technological assets and continuous monitoring of market need are still under-researched, this conceptual paper highlighted possible areas for empirical study.

\section{Corresponding Author}

Mohamad Faizal Ahmad Zaidi, Email: mdfaizal@uum.edu.my

\section{References}

Barczak, G., Griffin, A., \& Kahn, K. B. (2009). Perspective: Trends and Drivers of Success in NPD Practices: Results of the 2003 PDMA Best Practices Study. Journal of Product Innovation Management, 26(3-23). DOI:10.1111/j.1540-5885.2009.00331.x

Bhutto, A. (2005). Managing Interindustry Differences through Dynamic Capabilities: The Case Study of Nokia. International Journal of Innovation and Technology Management, 2(3), 235-257. DOI:10.1142/S0219877005000514

Biedenbach, T., \& Soderholm, A. (2008). The Challenge of Organizing Change in Hypercompetitive Industries: A Literature Review. Journal of Change Management, 8(2), 123-145. DOI:10.1080/14697010801953967

Bonabeau, E., Bodick, N., \& Armstrong, R. W. (2008). A More Rational Approach to NewProduct Development. Harvard Business Review, 96-102.

Calantone, R. J., Schmidt, J. B., \& Song, X. M. (1996). Controllable Factors of New Product Success: A Cross-National Comparison. Marketing Science, 15(4), 341-358. DOI:10.1287/mksc.15.4.341 
Calantone, R., Garcia, R., \& Droge, C. (2003). The Effects of Environmental Turbulence on New Product Development Strategy Planning. Journal of Product Innovation Management, 20, 90-103. DOI:10.1111/1540-5885.2002003

Cañibano, C., Encinar, M.-I., \& Muñoz, F.-F. (2006). Evolving Capabilities and Innovative Intentionality: Some Reflections on the Role of Intention within Innovation Processes. Innovation: Management, Policy and Practice, 8(4/5), 310-321. DOI: 10.5172/impp.2006.8.4.310

Cavusgil, E., Seggie, S. H., \& Talay, M. B. (2007). Dynamic Capabilities View: Foundations Research Agenda. Journal of Marketing Theory and Practice, 15(2), 159-166. DOI:10.2753/MTP1069-6679150205

Chen, H.-H., \& Lee, P.-Y. (2009). The Driving Drivers of Dynamic Competitive Capabilities: A New Perspective on Competition. European Business Review, 21(1), 78-91. DOI:10.1108/09555340910925193

Cohen, M. A., Eliashberg, J., \& Ho, T.-H. (1996). New Product Development: The Performance and Time-to-Market Tradeoff. Management Science (42), 2. DOI:10.1287/mnsc.42.2.173

Cooper, R. G. (2005). Attention: Results are Down! Your NPD Portfolio may be Harmful to your Business's Health. PMDA Visions, XXIX(2), 3-13.

Cooper, R. G., \& Edgett, S. J. (2001). Portfolio Management for New Products: Picking the Winners. Product Development Institute, Ancaster, Ontario, Canada.

Craig, A., \& Hart, S. (1992). Where to Now in New Product Development Research? European Journal of Marketing, 26(11), 2-49. DOI:10.1108/03090569210023037

Czakon, W. (2009). Relational Capability of Organizations - Theoritical Advances. Journal of Economics and Management, 5, 47-65.

Danneels, E. (2008). Organizational Antecedents of Second-order Competences. Strategic Management Journal, 9(5), 519-543. DOI:10.1002/smj.684

Deeds, D. L., DeCarolis, D., \& Coombs, J. (1999). Dynamic capabilities and New Product Development in High Technology Ventures: An Empirical Analysis of New Biotechnology Firms. Journal of Business Venturing, 15, 211-229. DOI:10.1016/S0883-9026(98)00013-5

Dougherty, D. (1992). Interpretive Barriers to Successful Product Innovation in Large Firms. Organization Science, 3(2), 179-202. DOI:10.1287/orsc.3.2.179

Døving, E., \& Gooderham, P. N. (2008). Dynamic Capabilities as Antecedents of the Scope of Related Diversification: The Case of Small Firm Accountancy Practices. Strategic Management Journal, 29(8), 841-857. DOI:10.1002/smj.683

Eisenhardt, K. M., \& Martin, J. A. (2000). Dynamic Capabilities: What are They? Strategic Management Journal, 21, 1105-1121. DOI:10.1002/10970266(200010/11)21:10/11<1105::AID-SMJ133>3.0.CO;2-E

Garcia, R., \& Calantone, R. (2002). A Critical Look at Technological Innovation Typology and Innovativeness Terminology: A Literature Review. The Journal of Product Innovation Management, 19, 110-132. DOI:10.1016/S0737-6782(01)00132-1

Greve, H. R. (2007). Exploration and Exploitation in Product Innovation. Industrial and Corporate Change, 1-31. DOI:10.1111/radm.12012

Griffin, A. (2002). Product Development Cycle Time for Business-to-Business Products. International Marketing Management, 31, 291-304. 
Guttel, W. H., \& Konlechner, S. W. (2009). Continuously Hanging by a Thread: Managing Contectually Ambidextrous Organizations. Schmalenbach Business Review (SBR), 61(2), 150-172.

Harreld, J.B., O’Reilly, C. A., \& Tushman, M. L. (2007). Dynamic Capabilities at IBM: Driving Strategy into Action. California Management Review, 49(4), 21-43. DOI:10.1225/CMR370

Helfat, C. E. (1997). Know-How and Asset Complementarity and Dynamic Capability Accumulation: The Case of R, \& D. Strategic Management Journal, 18(5), 339-360. DOI:10.1002/(SICI)1097-0266(199705)18:5<339::AID-SMJ883>3.0.CO;2-7

Helfat, C. E., \& Peteraf, M. A. (2003). The Dynamic Resource-based View: Capability Lifecycles. Strategic Management Journal, 24, 997-1010. DOI:10.1002/smj.332

Helfat, C. E., Finkelstein, S., Mitchell, W., Peteraf, M. A., Singh, H., Teece, D. J., et al. (2007). Dynamic Capabilities: Understanding Strategic Change in Organizations. USA: Blackwell Publishing.

Ho, Y.-C., \& Tsai, T.-H. (2006). The Impact of Dynamic Capabilities with Market Orientation and Resource-Based Approaches on NPD Project Performance. Journal of American Academy of Business, 8(1), 215-229.

Hohenegger, J., Bufardi, A., \& Xirouchakis, P. (2007). A New Concept of Compatibility Structure in New Product Development. J. Adv. Eng. Informatics, 21(1), 101-116. DOI:10.1016/i.aei.2006.09.005

Khalil, T. M. (2000). Management of Technology: The Key to Competitiveness and Wealth Creation. Boston: McGraw-Hill.

Kolk, A., \& Puumann, K. (2008). Co-Development of Open Innovation Strategy and Dynamic Capabilities as a Source of Corporate Growth. Working papers in Economics, 25(168180), 73-83.

Krasnikov, A., \& Jayachandran, S. (2008). The Relative Impact of Marketing, Research-andDevelopment, and Operations Capabilities on Firm Performance. Journal of Marketing, 72, 1-11. DOI:10.1509/jmkg.72.4.1

Kylaheiko, K., \& Sandstrom, J. (2007). Strategic Options-based Framework for Management of Dynamic Capabilities in Manufacturing Firms. Journal of Manufacturing Technology Management, 18(8), 966-984. DOI:10.1108/17410380710828280

Lawson, B., \& Samson, D. (2001). Developing Innovation Capability in Organizations: A Dynamic Capabilities Approach. International Journal of Innovation Management, 5(3), 377-400. DOI:10.1142/S1363919601000427

Lee, H., \& Kelley, D. (2008). Building Dynamic Capabilities for Innovation: An Exploratory Study of Key Management Practices. R, \& D Management, 38(2), 155-168. DOI:10.1111/j.1467-9310.2008.00506.x

Levinthal, D. A., \& March, J. G. (1993). The Myopia of Learning. Strategic Management Journal, 14, 5-112. DOI:10.1002/smj.4250141009

Liao, J. J., Kickul, J. R., \& Ma, H. (2009). Organizational Dynamic Capability and Innovation: An Empirical Examination of Internet Firms. Journal of Small Business Management, 47(3), 263-286. DOI:10.1111/j.1540-627X.2009.00271.x 
Majumdar, S. K. (1999). Sluggish Giants, Sticky Cultures, and Dynamic Capability Transformation. Journal of Business Venturing, 15, 59-78. DOI:10.1016/S08839026(98)00010-X

Makadok, R. (2001). Toward a Synthesis of the Resource-based and Dynamic-capability Views of Rent Creation. Strategic Management Journal, 22, 387-401. DOI:10.1002/smj.158

March, J. G. (1991). Exploration and Exploitation in Organizational Learning. Organization Science, 2(1), 71-87. DOI:10.1287/orsc.2.1.71

Marsh, S. J., \& Stock, G. N. (2006). Creating Dynamic Capability: The Role of Intertemporal Integration, Knowledge Retention, and Interpretation. The Journal of Product Innovation Management, 23(5), 422-436. DOI:10.1111/j.1540-5885.2006.00214.x

Menon, A., Chowdhury, J., \& Lukas, B. A. (2002). Antecedents and Outcomes of New Product Development Speed: An Interdisciplinary Conceptual Framework. Industrial Marketing Management, 31, 317-328. DOI:10.1108/03090560410511195

O'Connor, G. C. (2008). Major Innovation as a Dynamic Capability: A Systems Approach. The Journal of Product Innovation Management, 25, 313-330. DOI:10.1111/j.15405885.2008.00304.x

Page, A. L. (1993). Assessing New Product Development Practices and Performance: Establishing Crucial Norms. Journal of Product Innovation Management, 10, 273-290. DOI:10.1111/1540-5885.1040273

Pan, S., Pan, G., \& Hsieh, M. H. (2006). A Dual-level Analysis of the Capability Development Process: A Case Study of TT, \&T. Journal of the American Society for Information Science, \& Technology, 57(13), 1814-1829. DOI:10.1002/asi.v57:13

Poolton, J., \& Barclay, I. (1998). New Product Development from Past Research to Future Applications. Industrial Marketing Management, 27(3), 197-212.

Ray, P. K., Ida, M., Chung-Sok, S., \& Rhaman, S.-U. (2004). Dynamic Capabilities of Japanese and Korean Enterprises and the "Flying Geese" of International Competitiveness. Asia Pacific Business Review, 10(3/4), 463-484. DOI:10.1080/1360238042000264469

Rothaermel, F. T., \& Alexandre, M. T. (2009). Ambidexterity in Technology Sourcing: The Moderating Role of Absorptive Capacity. Organization Science, 20(4), 759-780. DOI:10.1287/orsc.1080.0404

Salomo, S., Gemunden, H. G., \& Leifer, R. (2007). Research on Corporate Radical Innovation Systems - A Dynamic Capabilities Perspective: An Introduction. Journal of Engineering and Technology Management, 24, 1-10. DOI:10.1016/i.jengtecman.2007.01.001

Schreyogg, G., \& Kliesch-Eberl, M. (2007). How Dynamic can Organizational Capabilities Be? Towards a Dual-process Model of Capability Dynamization. Strategic Management Journal, 28, 913-933. DOI:10.1002/smj.613

Song, X. M, Montoya-Weiss, M. M., \& Schmidt, J. B. (1997). Antecedents and Consequences of Cross-Functional Cooperation: A Comparison of R\&D, Manufacturing, and Marketing Perspectives. Journal of Product Innovation Management, 14(1), 35-47. DOI:10.1111/1540-5885.1410035

Teece, D. J. (1986). Profiting from Technological Innovation: Implications for Integration, Collaboration, Licensing and Public Policy. Research Policy, 15, 285-305. 
Teece, D. J. (2007). Explicating Dynamic Capabilities: The Nature and Microfoundations of (Sustainable) Enterprise Performance. Strategic Management Journal. DOI:10.1002/smj.640

Teece, D. J., Pisano, G., \& Shuen, A. (1997). Dynamic Capabilities and Strategic Management. Strategic Management Journal, 18(7), 509-533. DOI:10.1002/(SICI)10970266(199708)18:7<509::AID-SMJ882>3.0.CO;2-Z

Wang, C. L., \& Ahmed, P. K. (2007). Dynamic Capabilities: A Review and Research Agenda. International Journal of Management Reviews, 9(1), 31-51. DOI:10.1111/j.14682370.2007.00201.x

Wang, E., Klein, G., \& Jiang, J. J. (2007). IT Support in Manufacturing Firms for a Knowledge Management Dynamic Capability Link to Performance. International Journal of Production Research, 45(11), 2419-2434. DOI:10.1080/00207540601020437

Winter, S. G. (2003). Understanding Dynamic Capabilities. Strategic Management Journal, 24, 991-995. DOI:10.1002/smj.318

Wu, J.-H., \& Hisa, T.-L. (2008). Developing E-Business Dynamic Capabilities: An Analysis of ECommerce Innovation from I-, M-, to U-Commerce. Journal of Organizational Computing and Electronic Commerce, 18(2), 95-111. DOI:10.1080/10919390701807525

Wu, L.-Y. (2006). Resources, Dynamic Capabilities and Performance in a Dynamic Environment: Perceptions in Taiwanese IT Enterprises. Information , \& Management, 43, 447-454. DOI:10.1016/i.im.2005.11.001

Wu, L.-Y. (2007). Entrepreneurial Resources, Dynamic Capabilities and Start-up Performance of Taiwan's High-tech Firms. Journal of Business Research, 60, 549-555. DOI:10.1016/j.jbusres.2007.01.007

Wu, L.-Y. (2009). Applicability of the Resource-based and Dynamic-capability Views Under Environmental Volatility. Journal of Business Research, 1-5. DOI:10.1016/j.jbusres.2009.01.007

Wu, L.-Y., \& Wang, C.-J. (2007). Transforming Resources to Improve Performance of Technology-based Firms: A Taiwanese Empirical Study. Journal of Engineering and Technology Management, 24, 251-261. DOI:10.1016/i.jengtecman.2007.05.002

Zahra, S. A., Sapienza, H. J., \& Davidsson, P. (2006). Entrepreneurship and Dynamic Capabilities: A Review, Model and Research Agenda. Journal of Management Studies, 43(4), 917-955. DOI:10.1111/j.1467-6486.2006.00616.x

Zaidi, M.F.A., \& Othman, S.N. (2011a). Understanding Dynamic Capability as an Ongoing Concept for Studying Technological Capability. International Journal of Business and Social Science, 2(6), 224-234.

Zaidi, M.F.A., \& Othman, S.N. (2011b). Exploring the Concept of Technology Management through Dynamic Capability Perspective. International Journal of Business and Social Science, 2(5), 41-54.

Zaidi, M.F.A., \& Othman, S.N. (2012). Understanding the Concept of Dynamic Capabilities by Dismantling Teece, Pisano, and Shuen (1997)'s Definition. International Journal of Academic Research in Business and Social Sciences, 2(8), 367-378.

Zaidi, M.F.A., \& Othman, S.N. (2013). Sustaining Value Creation with Complementary Technologies Alignment. International Journal of Education and Research, 1(11), 1-12. 
Zhou, K. Z., \& Li, C. B. (2009). How Strategic Orientations Influence the Building of Dynamic Capability in Emerging Economies. Journal of Business Research, 1-8. DOI:10.1016/j.jbusres.2009.03.003

Zirger, B. J., \& Maidique, M. A. (1990). A Model of New Product Development: An Empirical Test. Management Science, 36(7), 867-883. DOI:10.1287/mnsc.36.7.867 